\title{
The importance of Gram positive bacteria as the cause of canine pyometra
}

\author{
A importância de bactérias Gram positivas como etiologia na \\ piometra canina
}

\author{
Marcos Cezar Sant' Anna ${ }^{1 *}$; Luiz Guilherme Corsi Trautwein²; \\ Lucienne Garcia Pretto Giordano ${ }^{3}$; Rebeca Cordeiro Justino'; \\ Karina Keller Marques da Costa Flaiban³; Maria Isabel Mello Martins ${ }^{3}$
}

\begin{abstract}
E. coli is the main bacteria isolated from infected uterus and bacterial endotoxin can lead to fatal endotoxic shock. Systemic inflammatory response syndrome (SIRS) precedes the endotoxic shock. Thus, early recognition of SIRS is important for patient treatment and prognostic. In Brazil, Gram positive bacteria are responsible for approximately $20 \%$ of all pyometra cases, and there is limited information about pathophysiology of shock and tissue injury. The aim of this study was to investigate the capacity of Gram positive bacteria to cause SIRS in bitches with pyometra. A prospective follow-up of 67 bitches with pyometra was performed, which were classified as SIRS + and SIRS- on admission. All bitches were surgically treated (ovariohysterectomy), uterine contents were collected in a sterile manner and the material was submitted to microbiological evaluation. Were identified in $55.2 \%$ of bitches E. coli (G1), 23.9\% other Gram negative bacteria (G2) and 20.9\% Gram positive bacteria (G3). The leukocyte profile, serum biochemistry and prevalence of SIRS were similar between the groups. It is concluded that Gram positive bacteria have the capacity to promote tissue damage and can lead the patient to death after SIRS and shock, as well as by E. coli and other Gram negative.
\end{abstract}

Key words: Bacteria etiology. Cystic endometrial hyperplasia. SIRS.

\section{Resumo}

A Escherichia coli é reportada como principal agente etiológico da piometra canina e as endotoxinas bacterianas podem desencadear choque endotóxico e óbito. A síndrome da resposta inflamatória sistêmica (SIRS) antecede o choque e sua identificação pode predizer o prognóstico do paciente. No Brasil, bactérias Gram positivas são responsáveis por aproximadamente $20 \%$ dos casos de piometra, e informações a respeito da fisiopatologia do choque ou da lesão tecidual nesses casos são escassos. Assim, o objetivo foi investigar a capacidade de bactérias Gram positivas desencadear SIRS em cadelas com piometra. Foram acompanhadas de maneira prospectiva 67 cadelas com piometra, que na admissão passaram por exame clínico, exames laboratoriais e foram classificadas como SIRS+ e SIRS-. Todos os animais foram tratados cirurgicamente (ovariohisterectomia), o conteúdo uterino foi coletado de forma estéril e o material foi submetido à avaliação microbiológica. Em 55,2\% das cadelas foi identificada E. coli (G1), 23,9\% outras bactérias Gram negativas (G2) e 20,9\% Gram positivas (G3). O perfil leucocitário, a bioquímica sérica e a prevalência de SIRS foram semelhantes entre os grupos. Conclui-se

\footnotetext{
${ }^{1}$ Discentes de Doutorado em Ciência Animal, Universidade Estadual de Londrina, UEL, PR, Brasil. E-mail: santannamarcos@bol. com.br; rebecacordeiro@gmail.com

2 Discente de Mestrado em Ciência Animal, UEL, Londrina, PR, Brasil. E-mail: contato@luizcorsi.vet.br

${ }^{3}$ Prof $^{\text {as }}$ Dr $^{\text {as }}$, UEL, Londrina, PR, Brasil. E-mail: lgiordano@uel.br; kkflaiban@uel.br; imartins@uel.br

* Author for correspondence
} 
que bactérias Gram positivas possuem capacidade de promover dano tecidual podendo levar o paciente a óbito após desencadear SIRS e choque, assim como por E. coli e outras Gram negativas.

Palavras-chave: Etiologia bacteriana. Hiperplasia endometrial cística. SIRS.

Pyometra results from complex etiological factors. These factors include hormones that are present in the uterine environment, virulence of infecting bacteria, the individual response to infection, and bacterial sensitivity against antimicrobial agents (HAGMAN, 2004; JITPEAN et al., 2014; SANT'ANNA et al., 2014).

Gram positive infections represent approximately $20 \%$ of bacterial etiology in pyometra (COGGAN, 2005; WEISS et al., 2004; SANT'ANNA et al., 2014). Several studies examining the pathophysiology of pyometra have determined the ability of E.coli to adhere to a specific receptor in progesterone-stimulated endometrium in response to endotoxin release. The endotoxin release may result in septic shock (VERSTEGEN et al., 2008). Cell wall components of Gram positive bacteria, such as peptidoglycans, also have the ability to induce the release of inflammatory cytokines (SPECHT et al., 2002). However, the prevalence of Gram positive infections in dogs with pyometra and your pathophysiology have not been evaluated.

The virulence of staphylococci is related to cell wall components, extracellular enzymes and toxins. These virulence factors cause a variety of biological effects on host tissue. Additionally, the production of exotoxins is associated with cytokine release, which causes necrotic lesions and toxic shock (COX, 2006).

The majority of infections by $\beta$-hemolytic streptococci in reproductive system dogs are caused by Streptococcus canis. The consequences of infection include abortions, infertility, genital infections, mastitis, and neonatal death (GREENE; PRESCOTT, 2006).
Gram-positive bacteria are an important public health problem, are present in $50 \%$ of sepsis in human patients and being widely studied. On the other hand, in veterinary literature this subject has not been approached (SPECHT et al., 2002; SUN et al., 2012).

The aim of this study was to investigate the capacity of Gram positive bacteria to cause SIRS in dogs with pyometra.

This study was approved by the ethics and animal experimentation committee of the Institutional University. All dog owners were consulted and informed of the procedures performed.

Sixty-seven bitches from different breeds with median age of 7.2 years (range, $1.5 \mathrm{y}$ to $14 \mathrm{y}$ ) were diagnosed with pyometra during a two-year period at Institutional Veterinary Hospital. The diagnosis was based on history, physical examination, hematology and imaging exams (radiographic and/or ultrasound). All animals were treated with ovariohysterectomy. The bitches received antibiotics and fluids as needed.

A clinical examination was performed at admission and the heart rate (HR), respiratory frequency $(f)$ and rectal temperature (T) data were collected. Animals were classified as positive for SIRS when they had two or more of following four criteria: $f>20$ breaths per minute, HR $>120$ beats per minute, $\mathrm{T}<38.1$ or $>39.2{ }^{\circ} \mathrm{C}$, total leukocyte count $<6$ or $>16 \times 10^{3} / \mathrm{mm}^{3}$ or percentage of band neutrophils $>3 \%$. These criteria have 97\% sensitivity in diagnosing patients with SIRS and have $64 \%$ specificity in classifying patients without SIRS (HAUPTMAN et al., 1997).

The blood samples were collected by puncture of jugular vein after antisepsis. The samples were 
separated into two tubes; one tube contained anticoagulant for hematology studies, and in other tube without anticoagulant was used for serum separation and subsequent biochemical tests. Blood counts were performed immediately after collection. The serum samples were placed in plastic tubes and stored at $-20{ }^{\circ} \mathrm{C}$. The serum was thawed at $5{ }^{\circ} \mathrm{C}$ and used for biochemical tests. Alanine amino transferase (ALT), alkaline phosphatase (ALP), blood urea nitrogen (BUN) and creatinine levels were determined by the kinetic method. Total protein (TP) was determined by the biuret method. The albumin content was determined by the colorimetric method using a BS-120 spectrophotometer (Mindray ${ }^{\circledR}$, China).

After removing the uterus, the contents of uterine horns were aseptically aspirated with a sterile needle and syringe. The contents were immediately sent to the microbiology laboratory. The cultures were grown on 5\% sheep blood agar (Himedia ${ }^{\circledR}$, Mumbai, India), and the plates were incubated aerobically at $37^{\circ} \mathrm{C}$ for 72 hours. The isolated microorganisms were analyzed by Gram staining, catalase, coagulase and esculin tests and $6.5 \% \mathrm{NaCl}$ tolerance (HOLT et al., 1994). Gramnegative bacteria were placed on MacConkey agar and identified by the Bactray system (Laborclin ${ }^{\circledR}$ Pinhais, Brazil).
The bitches were divided into three groups based on the bacterial culture results Escherichia coli positive in Group 1 (G1), other Gram negative in Group 2 (G2) and Gram positive in Group 3 (G3).

Statistical analyses were performed using Minitab 16 (2011) and Epi Info 6.04 (2001). The average values of erythrocytes, packed cell volume (PCV) and hemoglobin level were compared between groups using the analysis of variance and Tukey test. The median values of total leukocytes, mature neutrophils, band neutrophils, lymphocytes, BUN, creatinine, ALT, ALP, total protein, albumin, and glucose were compared between the groups using the Mann-Whitney test. The chi-square and Fisher exact test were used to determine the variables representing biomarkers with bacteriological analysis groups. The significance threshold was 5\% for all tests.

In this study, the bacteria culture was positive in $55.2 \%, 23.9 \%$ and $20.9 \%$ in $\mathrm{G} 1, \mathrm{G} 2$ and $\mathrm{G} 3$, respectively. The main bacteria isolated in $\mathrm{G} 2$ were Klebsiella spp and Pseudomonas spp. The main isolates in G3 were Streptococcus spp and Staphylococcus spp (Table 1). Weiss et al. (2004) and Emanuelli et al. (2012) found similar diversity in relation to the etiological agents of pyometra.

Table 1. Percentage of bacteria isolated from uterine secretions of 67 dogs with pyometra, Londrina-PR, 2012.

\begin{tabular}{cccc}
\hline Groups & Bacteria & (\% groups) & (\% total) \\
\hline G1 & E. coli & 100 & 55.20 \\
$(55.20 \%)$ & Klebsiellasp & 37.50 & 8.96 \\
& Pseudomonas sp & 31.25 & 7.46 \\
G2 & Salmonella sp & 12.50 & 2.99 \\
$(23.90 \%)$ & Proteus sp & 6.25 & 1.49 \\
& Citrobacterspp & 6.25 & 1.49 \\
& Serratialiquefaciens & 6.25 & 1.49 \\
\hline \multirow{2}{*}{ G3 } & Streptococcus spp & 64.30 & 13.43 \\
$(20.90 \%)$ & Staphylococcus spp & 28.60 & 5.97 \\
& Arcanobacterium pyogenes & 7.10 & 1.49 \\
\hline
\end{tabular}


The clinical signs of SIRS in pyometra are caused by release of cell wall components. Endotoxin is released into the circulation during bacterial growth or via the cell disintegration of Gram negative bacteria (HAGMAN et al., 2006). Nevertheless, the results obtained in this study showed the prevalence of SIRS and that the blood leukocyte counts were similar between cases of E.coli and Gram positive infection (Table 2). These results suggest pyometra by Gram positive bacteria causes SIRS similarly Gram negative infection.

Table 2. Comparison of clinical (SIRS) and laboratory findings between groups (G1, G2 and G3) by using Chisquared and Mann-Whitney tests at a significance level of 5\%, Londrina - PR, 2012.

\begin{tabular}{lcccc}
\hline Variables & G1 & G2 & G3 & P value \\
\hline $\begin{array}{l}\text { SIRS } \\
\text { Presence n/total (\%) } \\
\text { Absence n/total (\%) }\end{array}$ & $\begin{array}{c}28 / 54(51.85) \\
9 / 13(69.23)\end{array}$ & $\begin{array}{c}13 / 54(24) \\
3 / 13(23)\end{array}$ & $\begin{array}{c}13 / 54(24) \\
1 / 13(7.69)\end{array}$ & 0.382 \\
\hline $\begin{array}{l}\text { Total leukocytes } \\
\text { Median }\left(\mathrm{x} 10^{3} / \mathrm{mm}^{3}\right)\end{array}$ & 22,94 & 22,15 & 19,68 & 0.450 \\
\hline $\begin{array}{l}\text { Band neutrophils } \\
\text { Median }\left(/ \mathrm{mm}^{3}\right)\end{array}$ & 938 & 1,114 & 608 & 0.684 \\
\hline $\begin{array}{l}\text { Creatinine } \\
\text { Median mg/dl }\end{array}$ & 0.950 & 1.210 & 1.045 & 0.561 \\
\hline $\begin{array}{l}\text { Packed cell volume } \\
\text { Percentage }\end{array}$ & 35 & 36 & 46 & 0.080 \\
\hline $\begin{array}{l}\text { Erythrocytes } \\
\text { Median }\left(\mathrm{x} 10^{6} / \mathrm{mm}^{3}\right)\end{array}$ & 5,84 & 5,69 & 7,23 & 0.129 \\
\hline $\begin{array}{l}\text { Haemoglobin } \\
\text { Median }(\mathrm{g} / \mathrm{dl})\end{array}$ & 10.8 & 11.6 & 14.3 & 0.771 \\
\hline
\end{tabular}

The serum creatinine levels were similar between groups (Table 2). We expected that the E.coli cases would have elevated creatinine levels because pyometra caused by $E$. coli is associated with glomerulonephritis caused by immune-complex deposition (FIENI, 2006). In the study, azotemic patients were similar into groups, the results suggest that Gram positive bacteria also cause kidney damage. Studies that assessed the origin of the renal lesions in dogs with pyometra by urinary protein excretion and renal histopathology, showed the cause of renal injury may be multifactorial and its location is mixed, glomerular, tubular and interstitial (ZARAGOZA et al., 2004; HEIENE et al., 2007; MADDENS et al., 2011). However, the bacterial etiology was not addressed in these studies.
Pyometra caused by Gram positive infection also causes tissue damage and may lead to death by inducing SIRS, renal injury and shock. Our results indicate that further studies are needed to investigate the pathophysiology of SIRS and renal injury in bitches with pyometra due to Gram positive bacteria. It is critical to understand the disease pathophysiology to determine therapeutic or preventive measures and improve patient survival.

\section{Acknowledgments}

We thank the "Coordination of Improvement of Higher Education" (CAPES) Institute for financial support, as well as all of the teachers of VH-UEL, in particular Professor Dr.JosmariPirolo, the residents, 
and the Microbiology and Veterinary Clinical Pathology laboratories at VH-UEL.

\section{Author contributions}

All of the authors contributed equally to the work in this paper.

\section{Conflicts of interest}

The authors have declared no conflicts of interest.

\section{Ethics and animal experimentation committee of the UEL}

Numberof registry: 18/10

\section{References}

COGGAN, J. Estudo microbiológico de conteúdo intrauterino e histopatológico de útero de cadelas com piometra e pesquisa de fatores de virulência em cepas de E. coli e o potencial risco à saúde humana. 2005. Dissertação (Mestrado em Epidemiologia experimental e aplicada às zoonoses) - Faculdade de Medicina Veterinária e Zootecnia, Universidade de São Paulo, São Paulo.

COX, H. U. Staphylococcal infections. In: GREENE, C. E. Infectious diseases of the dog and cat. $3^{\text {th }}$ ed. Saint Louis: Saunders, 2006. p. 316-320.

EMANUELLI, M. P.; MARTINS, B. D.; WOLKMER, P.; ANTONIAZZI, A. Q.; EMANUELLI, T.; VARGAS, A. C.; LOPES, S. T. A. Complete blood count, total plasma protein, neutrophil oxidative metabolism, and lipid peroxidation in female dogs with pyometra associated with Escherichia coli. Comparative Clinical Pathology, London, v. 21, n. 3, p. 309-313, 2012. Available at: $<$ http://link.springer.com/article/10.1007\%2Fs00580010-1097-z>. Accessed at: 26 ago. 2015.

EPI Info ${ }^{\mathrm{TM}}$. Version 6.04. Atlanta: Center for Disease Control and Prevention, 2001. Disponível em: $<$ http:// www.cdc.gov/epiinfo>. Acesso em: 26, ago. 2015.

FIENI, F. Patologia de los ovários y el útero. In: WANKE, M. M.; GOBELLO, C. Reproduccion en caninos y felinos domesticos. Buenos Aires: Ed. Inter-Médica, 2006. p. 7589.
GREENE, C. E.; PRESCOTT, J. F. Streptococcal and other Gram-positive bacterial infections. In: GREENE, C. E. Infectious diseases of the dog and cat. $3^{\text {th }} \mathrm{ed}$. Saint Louis: Saunders, 2006. p. 302-315.

HAGMAN, R. New aspects of canine pyometra: studies on epidemiology and pathogenesis.2004. Thesis (Doctoral thesis in Small animal clinical sciences) Swedish University of Agricultural Sciences, Uppsala.

HAGMAN, R.; KINDAHL, H.; FRANSSON, B. A.; BERGSTRON, A.; HOLST, B. S.; LAGERSTEDT, A. S. Differentiation between pyometra and cystic endometrial hyperplasia/mucometra in bitch by prostaglandin F2 $\alpha$ metabolite analysis. Theriogenology, Stoneham, v. 66, n. 2, p. 198-206, 2006. Available at: <http://www. theriojournal.com/article/S0093-691X(05)00469-3/ abstract>. Accessed at: 26 ago. 2015.

HAUPTMAN, J. V.; WALSHAW, R.; OLIVER, N. B. Evaluation of the sensitivity and specificity of diagnostic criteria for sepsis in dogs. Veterinary Surgery, Knoxville, v. 26 , n. 5 , p. $393-397,1997$. Available at: $<$ http://www. ncbi.nlm.nih.gov/pubmed/9381665>. Accessed at: 26 ago. 2015 .

HEIENE, R.; KRISTIANSEN, V.; TEIGE, J.; JANSEN, J. H. Renal histomorphology in dogs with pyometra and control dogs, and long term clinical outcome with respect to signs of kidney disease. Acta Veterinaria Scandinavica, Copenhagen, v. 49, n. 13, p. 1-9, 2007. Available at: http://www.ncbi.nlm.nih.gov/pmc/articles/ PMC1868749/>. Accessed at: 26 ago. 2015.

HOLT, J.; KRIEG, N.; SNEATH, P. Bergey's manual of determinative bacteriology. $9^{\text {th }}$ ed. New York: Williams \& Wilkins, 1994. 679 p.

JITPEAN, S.; HOLST, B. S.; HOGLUND, O. V.; PETTERSON, A.; OLSSON, U.; STRAGE, E.; SODERSTEN, F.; HAGMAN, R. Serum insulin-like growth factor-I, iron, C-reactive protein, and serum amyloid A fron prediction of outcome in dogs with pyometra. Theriogenology, Stoneham, v. 82, n.1, p. 43-48, 2014. Available at: <http://www.theriojournal. com/article/S0093-691X(14)00110-1/abstract? $\mathrm{cc}=\mathrm{y}=>$. Accessed at: 26 ago. 2015.

MADDENS, B.; HEIENE, R.; SMETS, P.; SVENSSON, M.; ARESU, L.; VAN DER LUGT, J.; DAMINET, S.; MEYER, E. Evaluation of kidney injury in dogs with pyometra based on proteinuria, renal histomorphology, and urinary biomarkers. Journal of Veterinary Internal Medicine, Lakewood, v. 25, n. 5, p. 1075-1083, 2011. Available at: <http://www.ncbi.nlm.nih.gov/ pubmed/21848947>. Accessed at: 26 ago. 2015. 
MINITAB 16 statical softwere. Champaign, Illinois, 2011. Disponível em: $<$ http//www.minitab.com $>$. Acesso em: 26, ago. 2015.

SANT'ANNA, M. C.; GIORDANO, L. G. P.; FLAIBAN, K. K. M. C.; MULLER, E. E.; MATINS, M. I. M. Prognostic markers of canine pyometra. Arquivo Brasileiro de Medicina Veterinária e Zootecnia, Belo Horizonte, v. 66, n. 6, p. 1711, 2014. Disponível em: $\quad<$ http://www.scielo.br/scielo.php?pid=S0102$09352014000601711 \&$ script $=$ sci_arttext $>$. Acesso em: 26 ago. 2015.

SPECHT, A.; CHAN, D.; O'TOOLE, T.; KENT, M.; BENSON, J.; ROZANSKI, E. A; RUSH, J. E. Acute staphylococcal peritonitis following cystocentesis in a dog. Journal of Veterinary Emergency and Critical Care, New Jersey, v. 12, n. 3, p. 183-187, 2002.

SUN, D.; RAISLEY, B.; LANGER, M.; IYER, J. K.; VEDHAM, V.; BALLARD, J. L.; JAMES, J. A.; METCALF, J.; COGGESHALL, M. Anti-peptidoglucan antibodies and $\mathrm{Fcr}$ receptors are the key mediators of inflammation in gram-positive sepsis. The Journal of Immunology, Baltimore, v. 189, n. 5, p. 2423-2431, 2012.
VERSTEGEN, J.; DHALIWAL, G.; VERSTEGEN, K. Mucometra, cystic endometrial hyperplasia, and pyometra in the bitch: Advances in treatment and assessement of future reproductive success. Theriogenology, Stoneham, v. 70 , n. 3, p. 361-371, 2008. Available at: <http://www. ncbi.nlm.nih.gov/pubmed/18501959>. Accessed at: 26 ago. 2015.

WEISS, R. R.; CALOMENO, M. A.; SOUSA, R. S. Avaliação histopatológica, hormonal e bacteriológica da piometra na cadela. Archives of Veterinary Science, Curitiba, v. 9, n. 2, p. 981-87, 2004. Disponível em: $<$ http://ojs.c3sl.ufpr.br/ojs/index.php/veterinary/article/ view/4069>. Acesso em: 26 ago. 2015.

ZARAGOZA, C.; BARRERA, S.; CENTENO, F.; TAPIA, J. A.; MANE, M. C. Canine pyometra: a study of the urinary proteins by SDS-PAGE and Western blot. Theriogenology, Stoneham, v. 61, n. 7, p. 1259-1272, 2004. Disponível em: <http://www.ncbi.nlm.nih.gov/ pubmed/15036960>. Acesso em: 26 ago. 2015. 